\title{
РЕГУЛИРОВАНИЕ РАЗРАБОТКИ III ОБЪЕКТА МЕСТОРОЖДЕНИЯ АКШАБУЛАК ЦЕНТРАЛЬНЫЙ
}

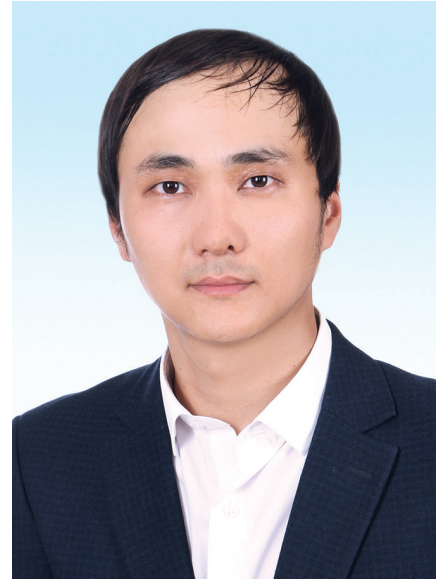

Б. ШИЛАНБАЕВ ${ }^{1 *}$, начальник отдела по моделированию месторождений, https://orcid.org/0000-00025299-1905

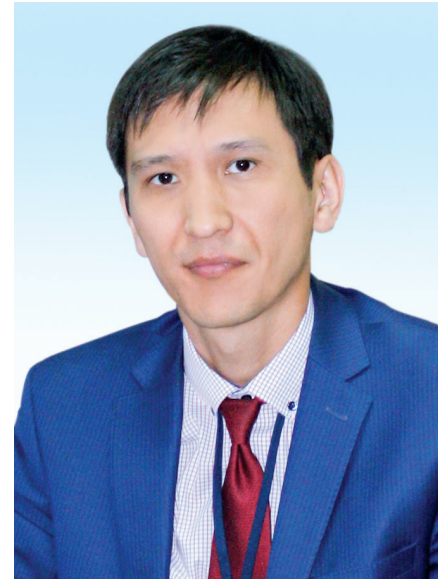

М. КӨЛДЕЙ заместитель генерального директора по геологии, главный геолог, https://orcid.org/0000-00018141-4122

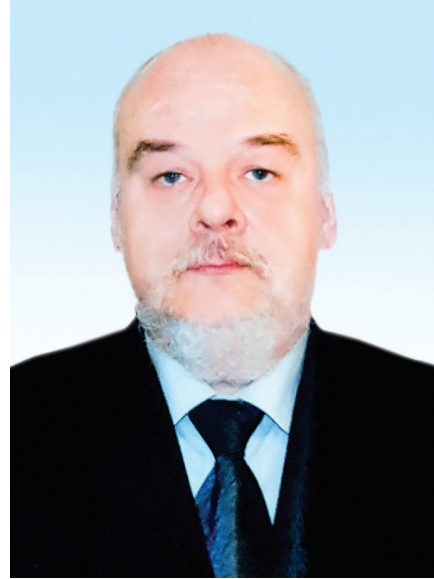

К. ГИЗЕМАНН ${ }^{1}$, директор департамента геологии и разработки, https://orcid.org/0000-00019938-4355

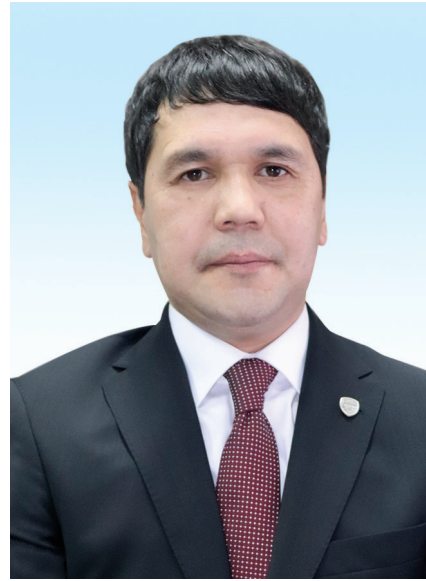

Н. ПРМАГАНБЕТОВ ${ }^{1}$, заместитель генерального директора по экономике и финансам,

https://orcid.org/0000-00031883-476X

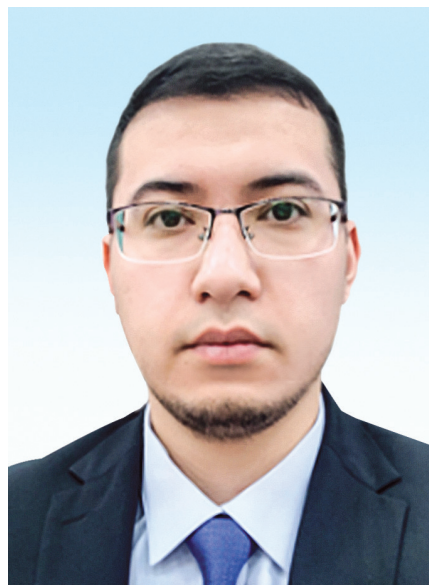

Т. ДЖАКСЫЛЫКОВ², руководитель проекта КГМ, КОА, КТМ и УО, https://orcid.org/0000-00021530-3974

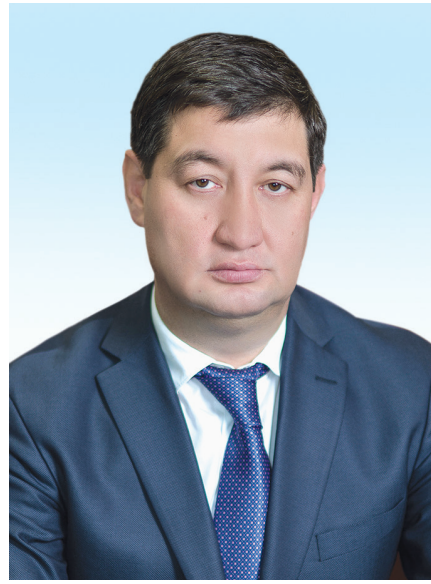

М. МУСТАФАЕВ ${ }^{1}$, первый заместитель генерального директора, https://orcid.org/0000-00024175-2140

* Адрес для переписки. E-mail: BShilanbayev@kgm.kz 
1 ТОО «СП «КАЗГЕРМУНАЙ»,

Республика Казахстан, 120018, г. Кызылорда, поселок Тасбогет, ул. Амангельды 100

2 ТОО «ҚАЗМҰНАЙГАЗ ИНЖИНИРИНГ» ФИЛИАЛ В ГОРОДЕ АТЫРАУ,

Республика Казахстан, 060000, город Атырау, ул. Зейнолла Кабдолов 1

Основная цель разработки месторождений уәлеводородов направлена на достижение максимального экономически рентабельного коэфффициента извлечения нефти. Одним из ключевых направлений в современных реалиях по праву является компьютерное моделирование, позволяющее реализовать многовариантный прогноз, по результатам которого имеется возможность выбрать рациональную стратегию разработки месторождения.

ТОО «СП «КАЗГЕРМУНАЙ» при разработке месторождений использует ряд технологий для повышения коэффициента извлечения нефти, в частности, полимерное заводнение на одном из объектов месторождения Нуралы, отдельно-раздельная закачка на I объекте месторождения Акшабулак Центральный.

В данной работе рассматривается оценка текущего состояния разработки по самому важному для компании III объекту месторождения Акшабулак Центральный и обоснование рационального плана дальнейшей его эксплуатации.

КЛЮЧЕВЫЕ СЛОВА: рациональная стратегия разработки, пластовое давление, коэффрициент извлечения нефрти, дисконтированный чистый доход

\section{ОРТАЛЫК АҚШАБҰЛАҚ КЕН ОРНЫНЫН III ОБЪЕКТІСІН ИГЕРУДI РЕТТЕУ}

Б. ШИЛАНБАЕВ ${ }^{1}$, кен орындарын модельдеу бөлімінің бастығы, https://orcid.org/0000-00025299-1905;

К. ГИЗЕМАНН ${ }^{1}$, геология және игеру департаментінің директоры, https://orcid.org/0000-00019938-4355;

Т. ЖАҚСыЛЫкОВ², ҚГМ, ҚОА, ҚТМ және УО жобасының басшысы, https://orcid.org/0000-00021530-3974;

М. КөЛДЕЙ ${ }^{1}$, бас директордың геология жөніндегі орынбасары - бас геолог, https://orcid. org/0000-0001-8141-4122;

Н. ПРМАҒАНБЕТОВ ${ }^{1}$, бас директордың экономика және қаржы мәселелері бойынша орынбасары, https://orcid.org/0000-0003-1883-476X;

М. МҰСТАФАЕВ ${ }^{1}$, бас директордың бірінші орынбасары, https://orcid.org/0000-0002-4175-2140

${ }^{1}$ «АЗГЕРМҰНАЙ» БК» ЖШС,

Қазақстан Республикасы, 120018, Қызылорда қ., Тасбағет кенті, Амангелді көшесі 100

${ }^{2}$ «ҚАЗМҰНАЙГАЗ ИНЖИНИРИНГ» ЖШС АТЫРАУ ФИЛИАЛЫ, Қазақстан Республикасы, 060000, Атырау қ., ЗейноллаҚабдолов к-сі, 1

Көмірсутектер кен орындарын заманауи игерудің негізгі мақсаты максималды экономикалық рентабельділікпен максималды мұнай шығарып алу коэффрициентіне жеткізуге бағытталған. Бұл жолдағы негізаі бағыттардың бірі көп нұсқалы болжамды іске асыруға және сол болжамдардың нәтижелері бойынша кен орынды игерудің ұтымды стратегиясын таңдауға мүмкіндік беретін компьютерлік модельдеу болып табылады.

"Қазгермұнай" БК " ЖШС әр түрлі уақытта кен орындарын игеру кезінде мұнай өндіру коэффрициентін арттыру үшін бірқатар технологияларды, атап айтқанда, Нұралы кен орны объектілерінің бірінде полимер айдау, Орталық Ақшабұлақ кен орнының I объектісінде қабаттарға суды бөліп айдау сияқты технологияларды пайдаланды және пайдаланады. Алайда, бұл жұмыста компания үшін ең маңызды Орталық Ақшабұлақ кен орны III объектісі бойынша игерудің ағымдағы жай-күйін бағалау және оны одан әрі пайдаланудың ұтымды жоспарын негіздеу қарастырылады.

ТҮЙІн СӨзДЕР: ұтымды даму стратегиясы, қабаттық қысым, мұнай шығарып алу коэфрфициенті, дисконтталған таза кіріс. 


\section{REGULATION OF THE EXPLOITATION OF THE III OBJECT OF THE AKSHABULAK CENTRAL FIELD}

B. SHILANBAYEV ${ }^{1}$, Head of Field Modeling Department, https://orcid.org/0000-0002-5299-1905; C. GIESEMANN ${ }^{1}$, Director of Geology and Development Department, https://orcid.org/0000-00019938-4355;

T. DZHASYLYKOV², Head of Project KGM, KOA, KTM and UO, https://orcid.org/0000-0002-15303974;

M. KOLDEY ${ }^{1}$, Deputy General Director for Geology - Head of Geology, https://orcid.org/0000-00018141-4122;

N. PRMAGANBETOV ${ }^{1}$, Deputy General Director for Economic and Finance, https://orcid.org/00000003-1883-476X;

M. MUSTAFAYEV'1 , First Deputy General Director, https://orcid.org/0000-0002-4175-2140

1JV KAZGERMUNAI LLP,

Republic of Kazakhstan, 120018, Kyzylorda town, Tasboget village, Amangeldy 100

${ }^{2}$ ATYRAU BRANCH KAZMUNAYGAZ ENGINEERING LLP,

Republic of Kazakhstan, 060000, Atyrau town, Zeinolla Kabdollov Street, 1

The main goal of the development of hydrocarbon deposits is aimed at achieving the maximum economically viable oil recovery rate. One of the key areas in modern realities is Reservoir modeling and simulation, which allows you to implement a multivariate forecast, according to the results of which it is possible to choose a rational strategy for the development of the field.

JV KazGerMunai LLP has used and is using technologies to increase the oil recovery rate at various times during the development of the fields, in particular, such as polymer flooding at one of the objects of the Nuraly field, Dual completion and simultaneous injection at I object of the Akshabulak Central field. However, this paper considers the assessment of the current state of development for the most important object for the company, the object III of the Akshabulak Central field and the rationale for a rational plan for its further operation.

KEY WORDS: rational development strategy, reservoir pressure, oil recovery factor, discounted net income.

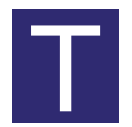

ОО «СП «Казгермунай» (далее - СП КГМ) имеет на балансе 6 отдельных месторождений нефти, газа и конденсата, в том числе Акшабулак Центральный, Акшабулак Восточный, Акшабулак Южный, Нуралы, Аксай и Аксай Южный, которые успешно разрабатываются на протяжении 20 лет. Выработанность извлекаемых запасов на текущий момент составляет 78\%, при утвержденном коэффициенте извлечения (далее КИН) - 0,53 д. ед. В 2009 г. добыча нефти достигла максимального уровня 3202 тыс. т в год. На протяжение 9 лет с 2007 по 2016 гг. СП КГМ стабильно поддерживало планку добычи нефти на уровне 3 млн т в год (рисунок 1). Доля добычи нефти на месторождении Акшабулак Центральный (далее III объект) составляет $82 \%$. III объект является уникальным по своим характеристикам, он приурочен к верхнеюрским отложениям кумкольской свиты.

С целью дальнейшей рациональной эксплуатации данного объекта в 2019 г. планировалось разработать и подобрать наиболее оптимальный вариант стратегии разработки объекта. Решению данной задачи и предварительно достигнутым результатам посвящена данная статья. 


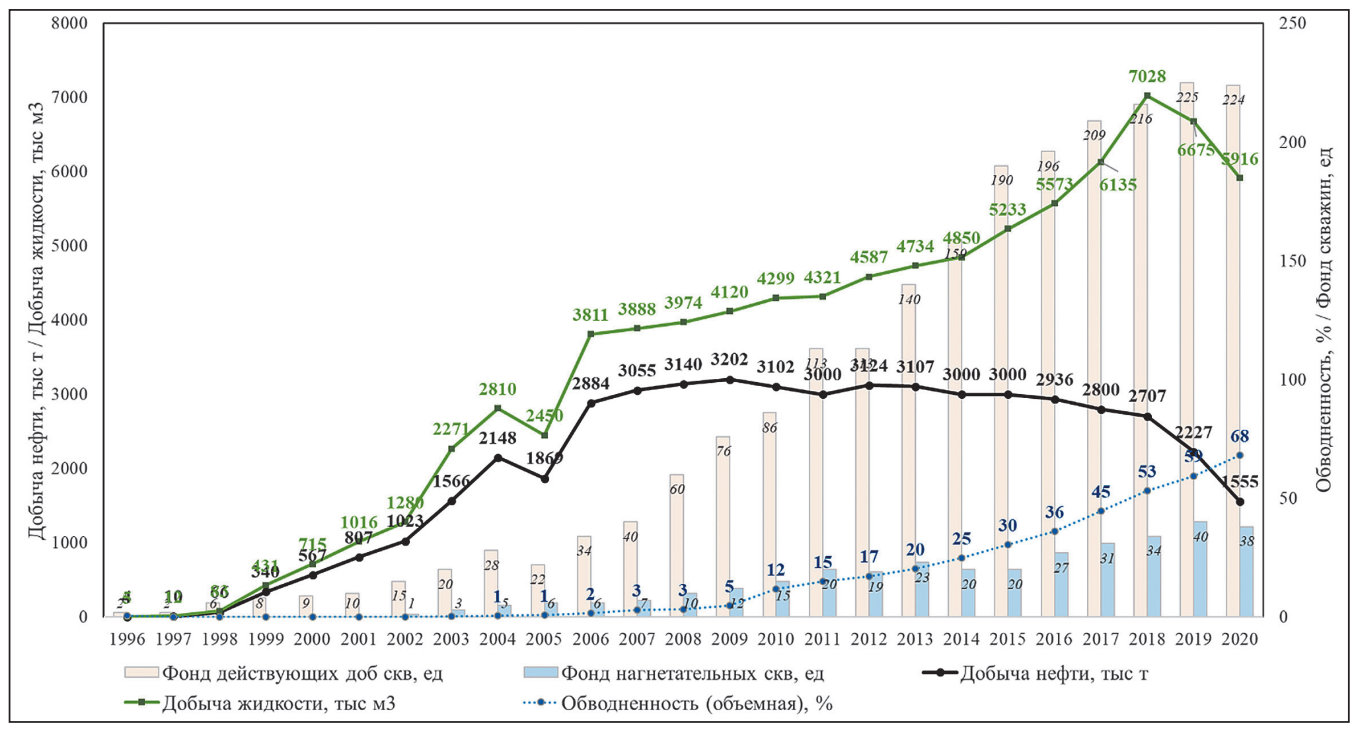

Рисунок 1 - График основных показателей разработки по ТОО «СП «КазГерМунай»

\section{АНАЛИЗ ТЕКУЩЕГО СОСТОЯНИЯ РАЗРАБОТКИ}

III объект представлен двумя горизонтами: верхним - карбонатным, с прослоями песчаных пород (Ю-IIІа) и нижним - песчаным (Ю-IIIt) с единым водонефтяным контактом. Эффективные нефтенасыщенные толщины коллекторов варьируют в пределах 1,7 - 21,9 м. Максимальная продуктивность равна 1697 м³/сут* МПа. По результатам лабораторных исследований керна, проницаемость варьирует в пределах 0,4 - 17 Да, и среднее значение равно 2,7 Да. При этом 62\% извлекаемых запасов (B+C1) СП КГМ сосредоточены на III объекте.

На рисунке 2 представлен график основных показателей разработки по III объекту и в целом по компании КГМ. По состоянию на 01.06.2019 выработка начальных извлекаемых запасов (далее НИЗ) по ІІІ объекту составляет 86\% и коэффициент извлечения нефти 0,63 д. ед. (при проектном 0,73 д. ед.). В период 2006 - 2018 гг. темп отбора от НИЗ держался на уровне 5,3\%. Закачка воды в пласт ведется с 2002 года. В качестве закачиваемого агента применяется попутно добываемая пластовая вода с месторождения Акшабулак Центральный, Восточный и Южный, которая частично ( 20\%) закачивается и на І объект месторождения Акшабулак Центральный.

Соотношение нагнетательных скважин к добывающим составляет $1 / 5$. Поддержание пластового давления (ППД) осуществляется девятью нагнетательными скважинами, которые расположены в законтурной области. На рисунке 3 представлен график, описывающий энергетическое состояние III объекта. С 2015 г. наблюдается снижение объемов закачки, а в 2018 г. она достигла минимального уровня. Компенсация отборов жидкости закачкой по состоянию на конец 2018 г. составила 37\%. Снижение объемов закачки объясняется началом организации системы ППД на I объекте месторождения Акшабулак Центральный.

В связи с активным расходом пластовой энергии и недостаточной компенсацией наблюдается тенденция к падению пластового давления. 


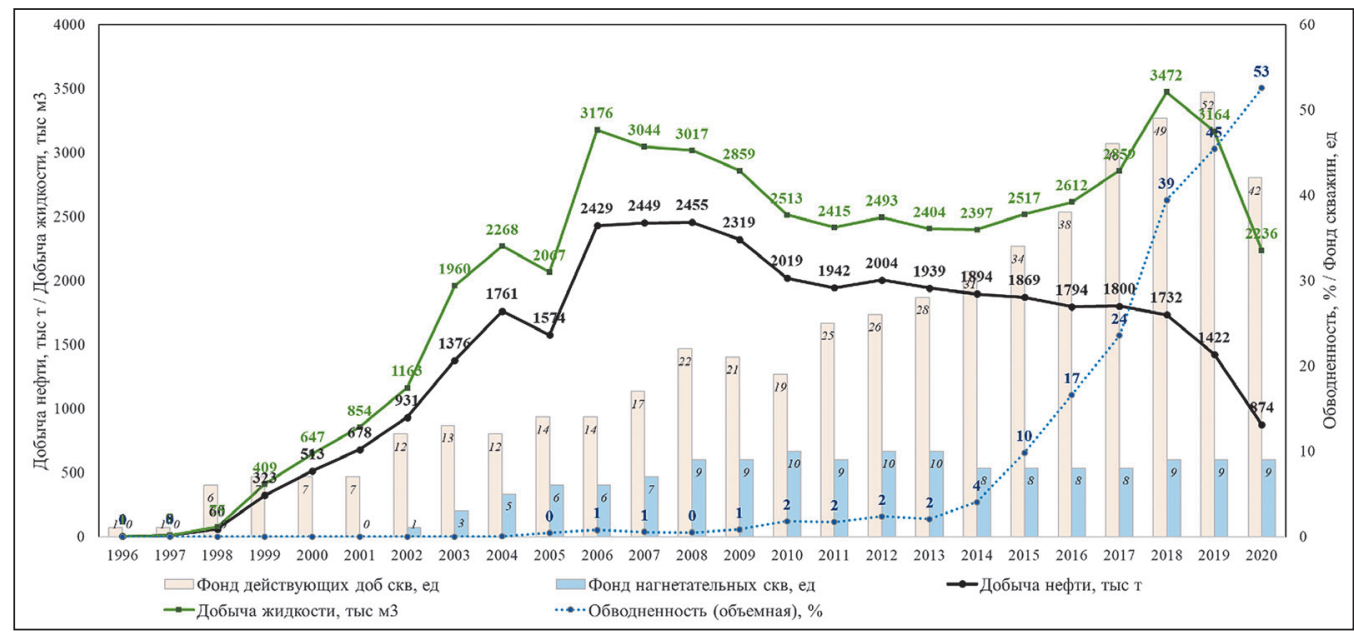

Рисунок 2 - График основных показателей разработки по III объекту месторождения Акшабулак Центральный

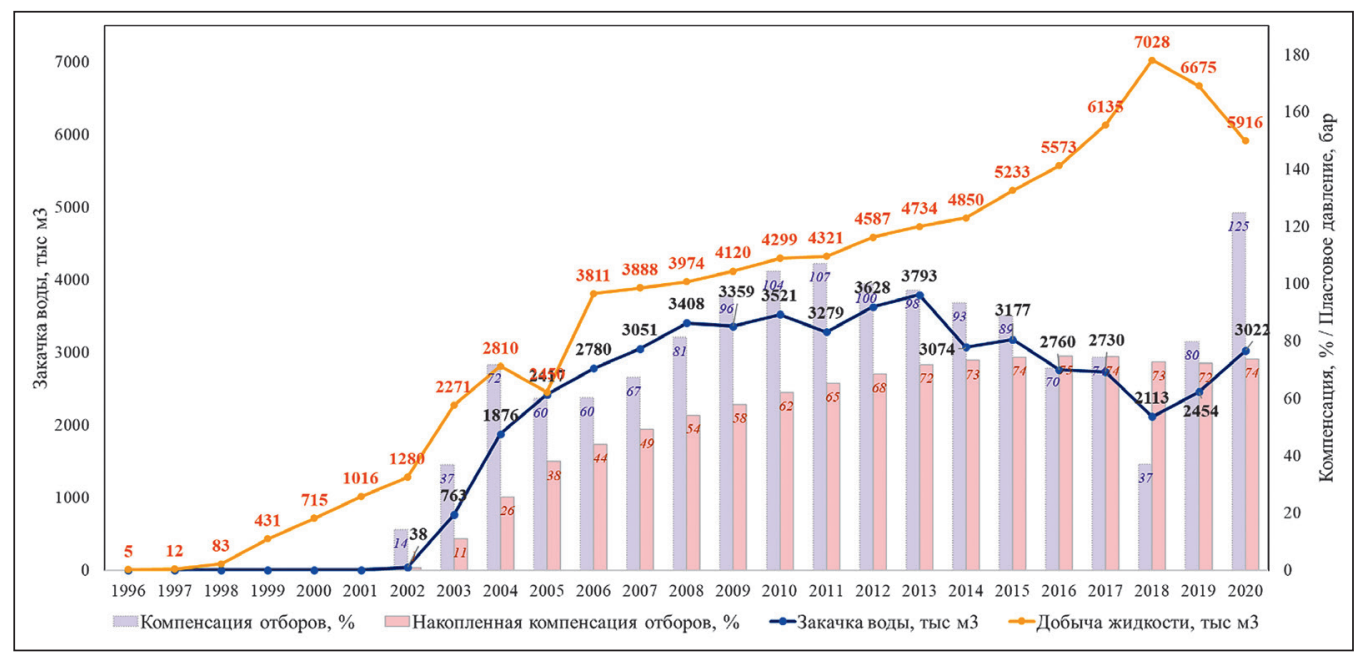

Рисунок 3 - Динамика добычи жидкости и закачки, а также текущей и накопленной компенсации по III объекту месторождения Акшабулак Центральный

\section{ОБОСНОВАНИЕ ОПТИМАЛЬНОЙ СХЕМЫ РАЗРАБОТКИ}

В связи с высокими темпами отбора извлекаемого сырья и значительным сокращением запасов, возникла необходимость пересмотра стратегии разработки путем решения проблем с текущим пластовым давлением. Для выбора варианта рациональной разработки III объекта месторождений Акшабулак Центральный рассчитывалось множество сценариев разработки. Основными критериями рациональности являлись следующие факторы:

1. Максимальный КИН и NPV за период рентабельной разработки.

Согласно Кодексу «О недрах и недропользовании» добыча должна проводиться методами и способами, исключающими потери углеводородов, не предусмотренные базовым проектным документом, в соответствии с положительной практикой поль- 


\section{ГЕОЛОГИЯ}

зования недрами [3]. Под положительной практикой использования недр понимается общепринятая международная практика, применяемая при проведении операции по недропользованию, которая является рациональной, безопасной, необходимой и экономический эффективной [4].

2. Стабилизация и увеличение пластового давления путем повышения эффективности системы заводнения.

С помощью статистических методов, исходя из прошедшего периода и текущего состояния залежи были рассчитаны десятки вариантов разработки по III объекту. Реализуемость данных расчетов проверялась симуляциями на постоянно действующей геолого-гидродинамической модели (ПДГГМ). На рисунке 4 и в таблице 1 представлены результаты по основным 6 вариантам.

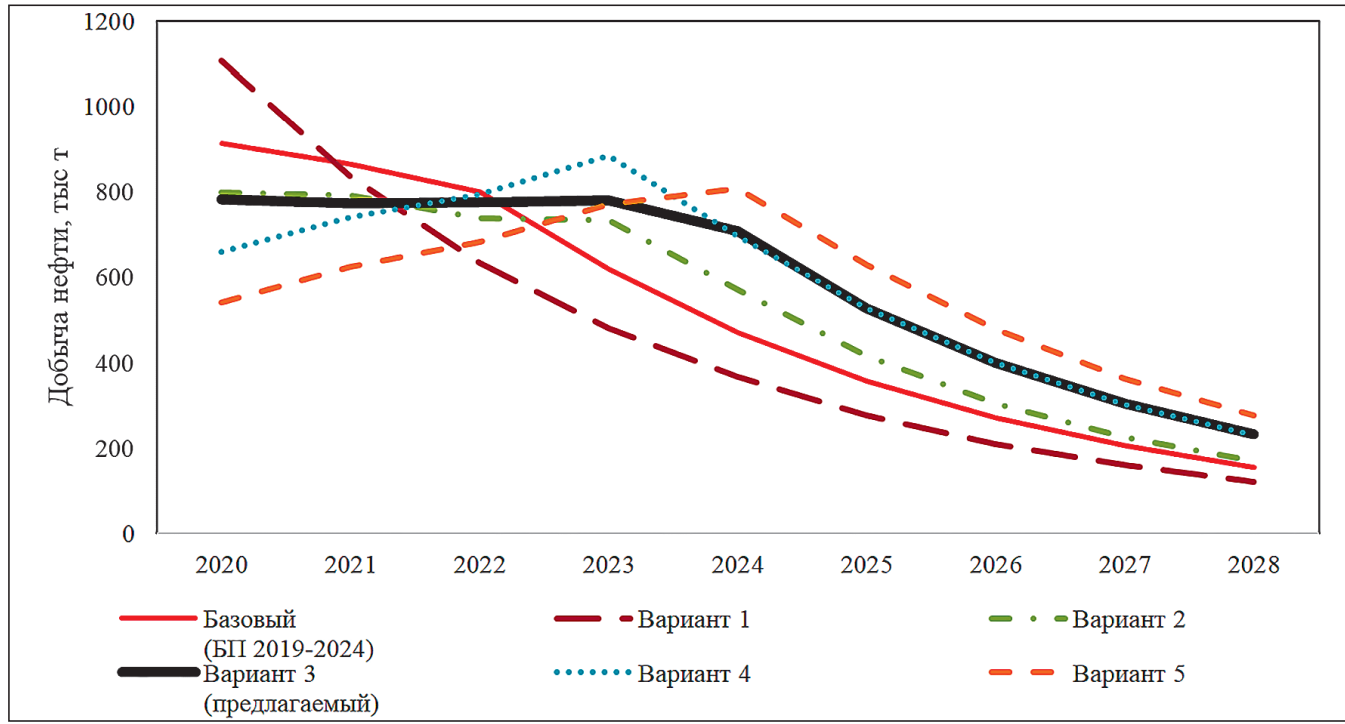

Рисунок 4 - Результаты расчета прогнозных вариантов

Как показывают расчеты, на фоне снижения пластового давления интенсивная добыча приводит к большим объемам извлечения в начальный период, но в последующие года имеет место существенное падение добычи. Форсированный отбор рекомендуется проводить на поздней стадии разработки, когда обводненность достигает более 75\% при наличии геолого-технической возможности [5]. Так как III объект находится в переходном состоянии от 2-ой на 3-ю стадию, форсирование отбора на рассматриваемом объекте является неприемлемым.

Варианты 3, 4 и 5 предусматривают добычу в более умеренном режиме со стабильными темпами отборов от начальных извлекаемых запасов до 2024 г. Принудительное снижение добычи в начальный период создает и достаточный промежуток времени, необходимый для восстановления пластовой энергии вследствие увеличения текущей компенсации отборов закачкой воды, что впоследствии приведет к повышению КИН.

С целью увеличения охвата месторождения заводнением и повышения эффективности системы ППД применяется перевод 2-х скважин под нагнетание (красный кружок) и отключение скважин с обводненностью более 95\% (рисунок 5). Для обе- 


\section{ГЕОЛОГИЯ}

Таблица 1 - Результаты прогнозных расчетов добычи нефти

\begin{tabular}{|c|c|c|c|c|c|c|c|c|c|c|c|c|c|}
\hline Показатель & Вариант & 2020 & 2021 & 2022 & 2023 & 2024 & 2025 & 2026 & 2027 & 2028 & $\begin{array}{c}\text { Итого } \\
3 a \\
2020- \\
2024\end{array}$ & $\begin{array}{c}\text { Итого } \\
3 a \\
2020- \\
2028\end{array}$ & $\begin{array}{l}\text { кин, } \\
\text { д.ед }\end{array}$ \\
\hline \multirow{6}{*}{$\begin{array}{l}\text { Добыча } \\
\text { нефти, } \\
\text { тыс т }\end{array}$} & $\begin{array}{c}\text { Базовый } \\
\text { вариант } \\
\text { (БП 2019-2024) }\end{array}$ & 914 & 865 & 800 & 618 & 470 & 356 & 270 & 205 & 156 & 3668 & 4654 & 0,727 \\
\hline & Вариант 1 & 1107 & 837 & 635 & 482 & 367 & 277 & 211 & 160 & 122 & 3428 & 4197 & 0,719 \\
\hline & Вариант 2 & 800 & 793 & 739 & 734 & 571 & 415 & 305 & 226 & 171 & 3636 & 4752 & 0,729 \\
\hline & $\begin{array}{c}\text { Вариант } 3 \\
\text { (предлагаемый) }\end{array}$ & 783 & 774 & 775 & 781 & 708 & 527 & 400 & 305 & 232 & 3820 & 5283 & 0,739 \\
\hline & Вариант 4 & 660 & 740 & 794 & 885 & 697 & 527 & 400 & 303 & 231 & 3775 & 5236 & 0,738 \\
\hline & Вариант 5 & 540 & 625 & 684 & 770 & 809 & 630 & 478 & 363 & 276 & 3428 & 5175 & 0,737 \\
\hline
\end{tabular}

спечения необходимой компенсации отбора жидкости закачкой воды было решено направить всю попутно-добываемую воду с месторождений Акшабулак Центральный, Южный и Восточный на закачивание в III объекте. Таким образом была решена проблема нехватки воды, необходимой для достаточной текущей компенсации, и в 2020 г. она составила 125\% против 37\% в 2018 г. При этом проблема ППД на прочих объектах месторождения Акшабулак Центральный была решена заменой закачиваемого агента на артезианскую воду. Расположенные на месторождениях мощности БКНС позволили организовать этот процесс в кратчайшие сроки, при

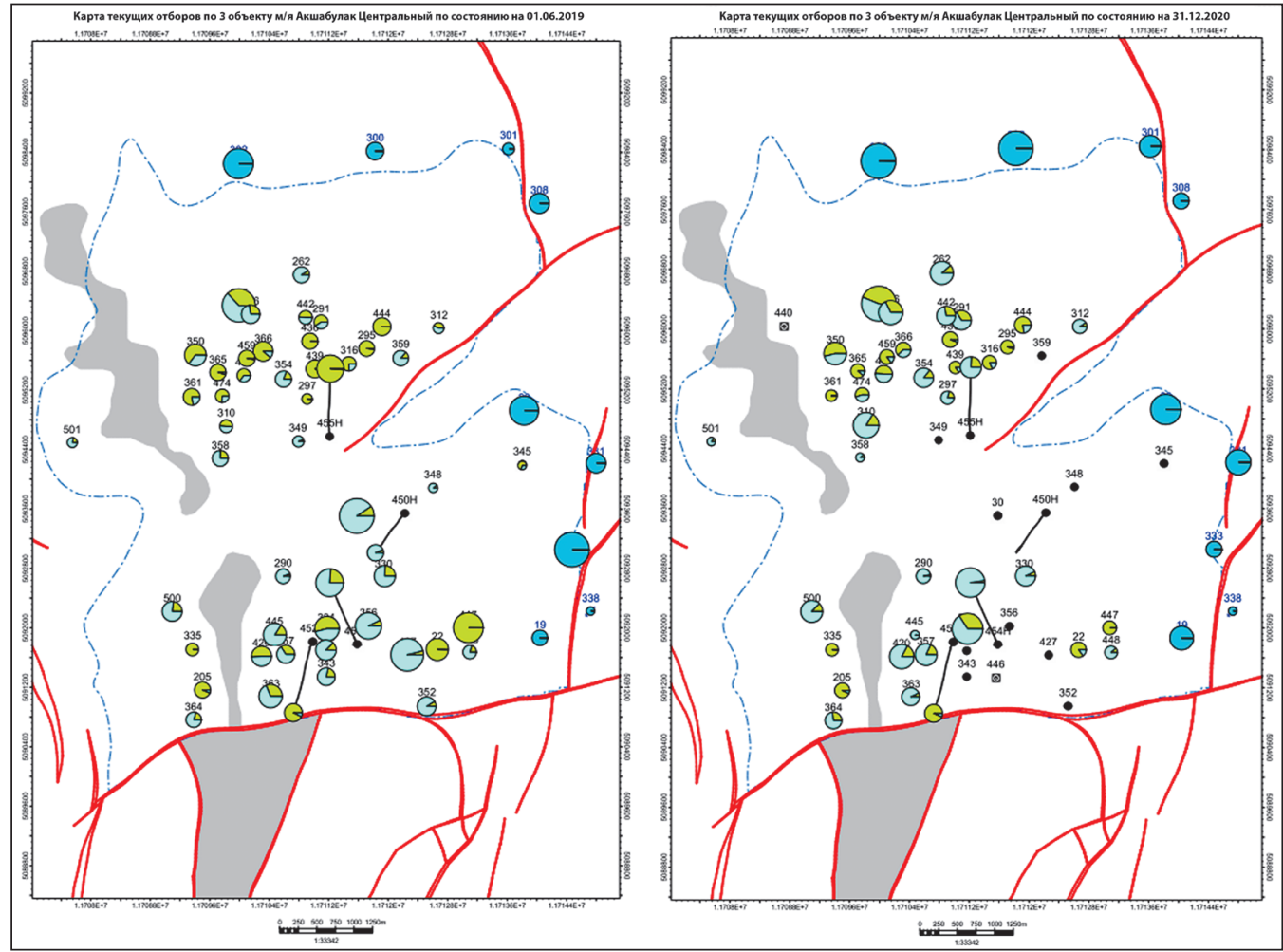

Рисунок 5 - Карта текущих отборов: слева - на 01.06.2019 г.; справа - на 01.01.2021 г. 


\section{ГЕОЛОГИЯ}

этом артезианская и попутно добываемая вода не смешиваются, поскольку закачиваются отдельными потоками разными насосами.

С целью оценки экономики по каждому варианту были рассчитаны ключевые показатели эффективности (NPV, чистая прибыль, рентабельный период и др.), что позволило сравнить характеристики сценариев разработки в целом по КГМ. Наиболее высокой экономической привлекательностью по результатам сравнения обладает вариант 3, где рассматривается снижение объемов добычи на 14,3\% в 2020 году и на $10,5 \%$ в 2021 году от объемов добычи принятом в ранее утвержденном бизнес плане.

По итогам 2020 года можно предварительно оценить результаты принятых решений и их эффект на разработку объекта. Так, например, впервые за всю историю разработки III объекта наблюдается положительная тенденция роста пластового давления (таблиц̧а 2). На рисунке 6 отображена динамика, нормированного от 0 до 1 пластового давления. По результатам гидродинамических исследований по скважинам наблюдается тенденция стабилизации и даже роста пластового давления.

Таблица 2 - Изменения темпа падения пластового давления по III объекту

\begin{tabular}{|c|c|c|}
\hline \multirow{2}{*}{ Год } & \multicolumn{2}{|c|}{ Темп падения пластового давления } \\
\cline { 2 - 3 } & Мпа & $\%$ \\
\hline 2018 & $-0,9$ & $-6 \%$ \\
\hline 2019 & $-0,7$ & $-5 \%$ \\
\hline 2020 & 0,8 & $6 \%$ \\
\hline
\end{tabular}

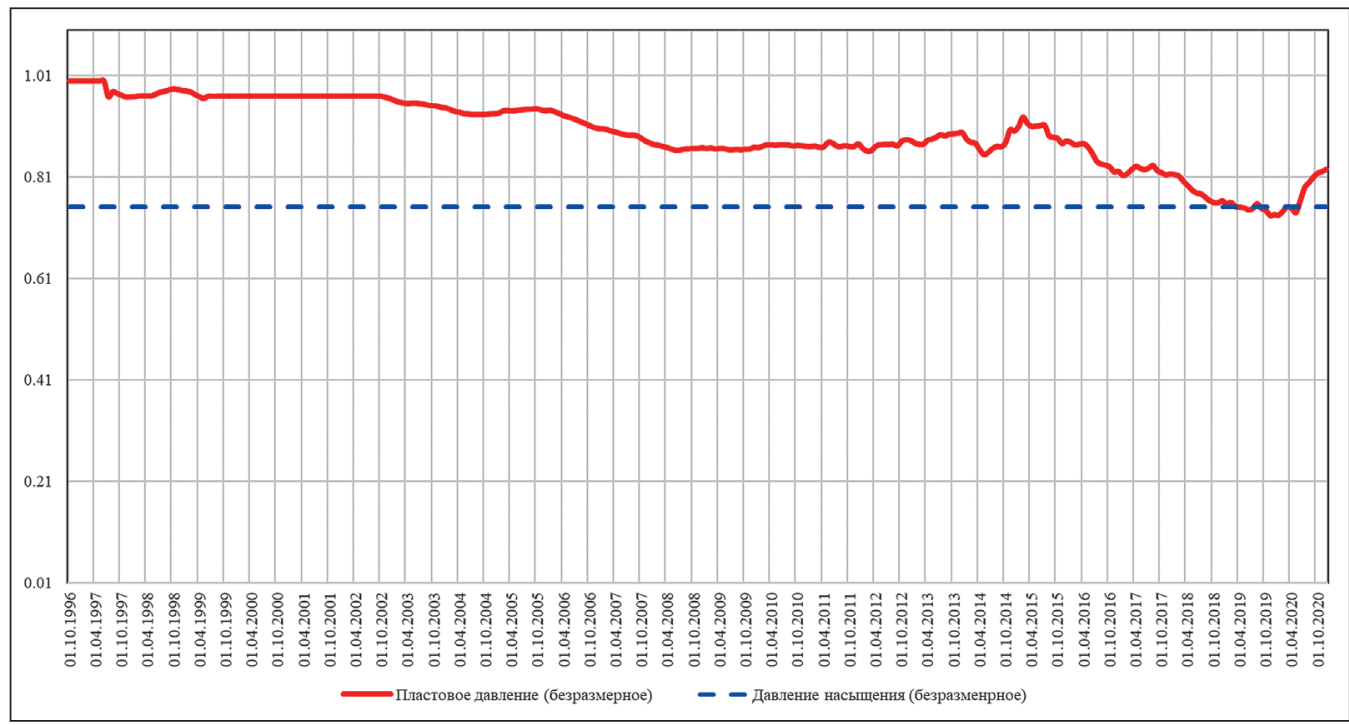

Рисунок 6 - Динамика пластового давления (нормированная) по III объекту месторождения Акшабулак Центральный

\section{ВЫВОДЫ}

По результатам проведенных работ были пересмотрена прежняя стратегия разработки месторождения и бизнес-план КГМ. Преимуществами предлагаемого варианта новой стратегии являются: 
1. Увеличение КИН на 1,7\% по ІІІ объекту;

2. Стабилизация компенсации отборов закачкой воды и восстановление пластовой энергии по III объекту;

3. Увеличение NPV (Net Present Value, чистая приведенная стоимость) на $~ 34,8 \%$ и увеличение чистой прибыли на $64,1 \%$;

4. Увеличение периода рентабельной деятельности компании.

Результаты данной работы были включены в анализ разработки месторождения Акшабулак Центральный, и успешно прошли защиту при рассмотрении на заседании ЦКРР МЭ РК (Центральная комиссия по разведке и разработке полезных ископаемых Министерства энергетики РК).

Таким образом, тесная интеграция геологического анализа, проектирования разработки и финансово-экономический анализ позволили выбрать рациональный вариант разработки с наилучшим экономическим эффектом, как для недропользователя, так и для государства.

\section{ЛИТЕРАТУРА}

1 Баюк Е.И. О влиянии давления на упругие и деформационно-прочностные свойства некоторых пород // Геофизический журнал. - 1985. - №2. - С. 82-86. [Bayuk E.I. O vliyanii davleniya na uprugie i deformacionno-prochnostnye svojstva nekotoryh porod // Geofizicheskij zhurnal. - 1985. - №2. - S. 82-86.]

2 Лысенко В.Д., Грайфер В.И. Рациональная разработка нефтяных месторождений. - М.: Недра-Бизнес центр, 2005. - 607 c. [Lysenko V.D., Grajfer V.I. Racional'naya razrabotka neftyanyh mestorozhdenij. - M.: OOO «Nedra-Biznescentr», 2005. - 607 s.]

3 Кодекс Республики Казахстан от 27.12.2017 г. №125-VI«О недрах и недропользовании». [Kodeks Respubliki Kazahstan ot 27.12.2017 g. №125-VI «O nedrah i nedropol'zovanii».]

4 Единые правила по рациональному и комплексному использованию недрот 15.06.2018 г. [Edinye pravila po racional'nomu i kompleksnomu ispol'zovaniyu nedrot 15.06.2018 g.] Казаков А.А. Форсированный отбор жидкости. - М.: Издательский дом Недра, 2020. - 332 c. [Kazakov A.A. Forsirovannyj otbor zhidkosti. - M.: Izdatel'skij dom Nedra, 2020. - 332 s.] 